\title{
Trigona branneri (Hymenoptera: Apidae) as a Collector of Honeydew from Aethalion reticulatum (Hemiptera: Aethalionidae) on Baubinia forficata (Fabaceae: Caesalpinoideae) in a Brazilian Savanna
}

by

Gudryan Jackson Barônio ${ }^{1}$, Ana Carolina Vieira Pires ${ }^{2}$ \& Camila Aoki ${ }^{3}$

\section{ABSTRACT}

The presence of aggregates of $A$. reticulatum on Baubinia has been reported, but the insects were mainly attended by ants of the genus Camponotus, and stingless beeswere not regularly recorded in aggregations. We observed a colony of thetreehopper $A$. reticulatum and stingless bees, Trigona branneri, interacting on Baubinia forficata (Fabaceae). Agonistic behavior was observed in bees when another individual of the same species or ants approached. Although this is not proof that the interaction between stingless bees and treehoppers is mutualistic, the interactions between ants and this insect are common and mutualistic. Thus, if T. branneri effectively provides protection for the aphids, a new mutualism can be the focus of future research to determine if the bee-aphid interactions have same ecological functions as the ant-aphid interactions.

Key words: Ant-aphid interaction, Camponotus, trophobiosis, stingless bees, hemipterans

\section{INTRODUCTION}

The interactions between species that coexist in time and space have an important role for biodiversity in the communities (Del-Claro 2004). Among

\footnotetext{
${ }^{1}$ Programa de Pós Graduação em Ecologia e Conservação de Recursos Naturais, Universidade Federal de Uberlândia. Av. Pará, s/n, Uberlândia, MG, CEP 38400902, Instituto de Biologia, Campus Umuarama, bloco 2D.

${ }^{2}$ Laboratório de Ecologia Evolutiva e Biodiversidade, Universidade Federal de Minas Gerais. Av. Presidente Antônio Carlos, 6627, Belo Horizonte, MG, CEP 30161970, Departamento de Biologia Geral, Bloco I3.

${ }^{3}$ Programa de Pós-Graduação em Ecologia e Conservação, Universidade Federal de Mato Grosso do Sul. Av. Costa e Silva, s/n, Campo Grande, MS, CEP 79070900, Centro de Ciências Biológicas e da Saúde.

${ }^{1}$ Author for correspondence: Gudryan Jackson Barônio (gudryan@gmail.com)
} 
the types of interactions, mutualisms are important processes for the structure and composition of communities (Way 1963; Stadler \& Dixon 2005; Bascompte \& Jordano 2007).

Symbiotic interactions have been reported involving Aethalion reticulatum Linnaeus 1767 with wasps or ants (Letourneau \& Choe 1987). There are other species associated with this treehopper, such as Synoeca septentrionalis (Vespidae) on Piper aduncum (Ramoni-Perazzi et al. 2006), and Polistes erythrocephalus on Solanaceae in Peru (MacCarroll \& Reeves 2004), and even stingless bees of the genus Trigona, which take advantage of treehoppers' sugary excretions (Castro 1975; Vieira et al. 2007; Oda et al. 2009).

Bees of the genus Trigona Jurine 1807, popularly known as Xupé, Mombuca and Arapuá, are common in the Neotropics (Michener 2000) and very important pollinators of the Brazilian Cerrado species (Almeida \& Laroca 1988, Nogueira-Neto 1997, Silva et al.2007), Amazon (Maués \& Couturier 2002) and cultivated species (Lorenzon et al. 1993; Silva et al. 1997). Some of these species have the behavior of robbing resources (nectar thiefs), negatively affecting the relationship between plants and pollinators (Murphy \& Breed 2008; Santos \& Absy 2010).

Baubinia forficata Link., belonging to the Fabaceae family, generally known as pata-de-vaca, is a thorny plant of 5 to 9 meters in height, and is heliophytic, deciduous or semi-deciduous (Lorenzi 2002). It is found in the Northern (Pernambuco, Bahia, Alagoas), Southern (Minas Gerais, Espírito Santo, São Paulo, Rio de Janeiro) and South (Paraná, Santa Catarina, Rio Grande do Sul) regions of Brazil (Lorenzi 2002; Vaz 2010). This species is commonly used as a shade tree in urban areas (Fowler 1992), which may explain their presence in other regions of the country that are not within the Cerrado. The presence of $A$. reticulatum aggregations in Baubinia has already been observed by Fowler (1992), but the insects were mainly attended by ants of the Camponotus genus, and no stingless bees or wasps were regularly recorded at the aggregations.

The goal of this work is show the interaction between the stingless bee Trigona branneri Cockreall, 1912 and the treehopper $A$. reticulatum.

\section{MATERIAL AND METHODS}

We observed interactions between $A$. reticulatum and T. branneri three times daily for four consecutive days in August and September 2009 in one 
individual of Bauhinia forficata in Parque Nacional das Emas, GO, Brazil. Our observations were at 6:00, 12:00 and 18:00 hours, lasting at least 60 minutes each.

The treehopper $A$. reticulatum is a small $(<10 \mathrm{~mm})$ rusty brown sucking insect which lives in colonies made up of young wingless nymphs and winged adults (Santana et al.2005). Individuals feed on by sucking the content of leaf tissues from host plants and releasing a carbohydrate-rich solution known as honeydew (Gallo et al. 2002). Drops of this sweet substance are consumed by ants, bees and other insects (Brown 1976). Through continuous sap sucking, treehoppers negatively affect the growth and development of host plants to the extent of killing the plant in the most severe cases (Gallo et al. 2002; Santana et al. 2005).

\section{RESULTS}

We detected the presence of 19 individuals of Trigona banneri collecting honeydew exudates of eight individual $A$. reticulatum adults and 167 nymphs of the same species. On $B$. forficata, these stingless bees touched primarily the proximal upper abdomen of $A$. reticulatum with their front legs and antennas. The bees repeated the stimulus toward the distal part of the abdomen where the exudate droplet was collected with the first pair of legs and inserted into the proboscis. This behavior of the bees was recorded in both adult treehoppers and their nymphs, although there was always at least one adult on the same branch as the nymphs. The behavior was clearly observed in individuals in nymphal stages. However, the stimulus in adults across the back of the $A$. reticulatum abdomen was not observed with the same frequency as in the nymphs (Fig. 1).

In the early hours of the morning and late afternoon there were no bees around the aggregations and the presence of at most three Camponotus ants patrolling on insects were observed, but without collecting honeydew. We did not find ant nests in proximity to host plant.

Agonistic behavior was observed in bees when touched by another individual of the same species or by very close ants. After they raised their wings partially as a warning sign, they started a short flight over the $A$. reticulatum colony (Fig. 2). 


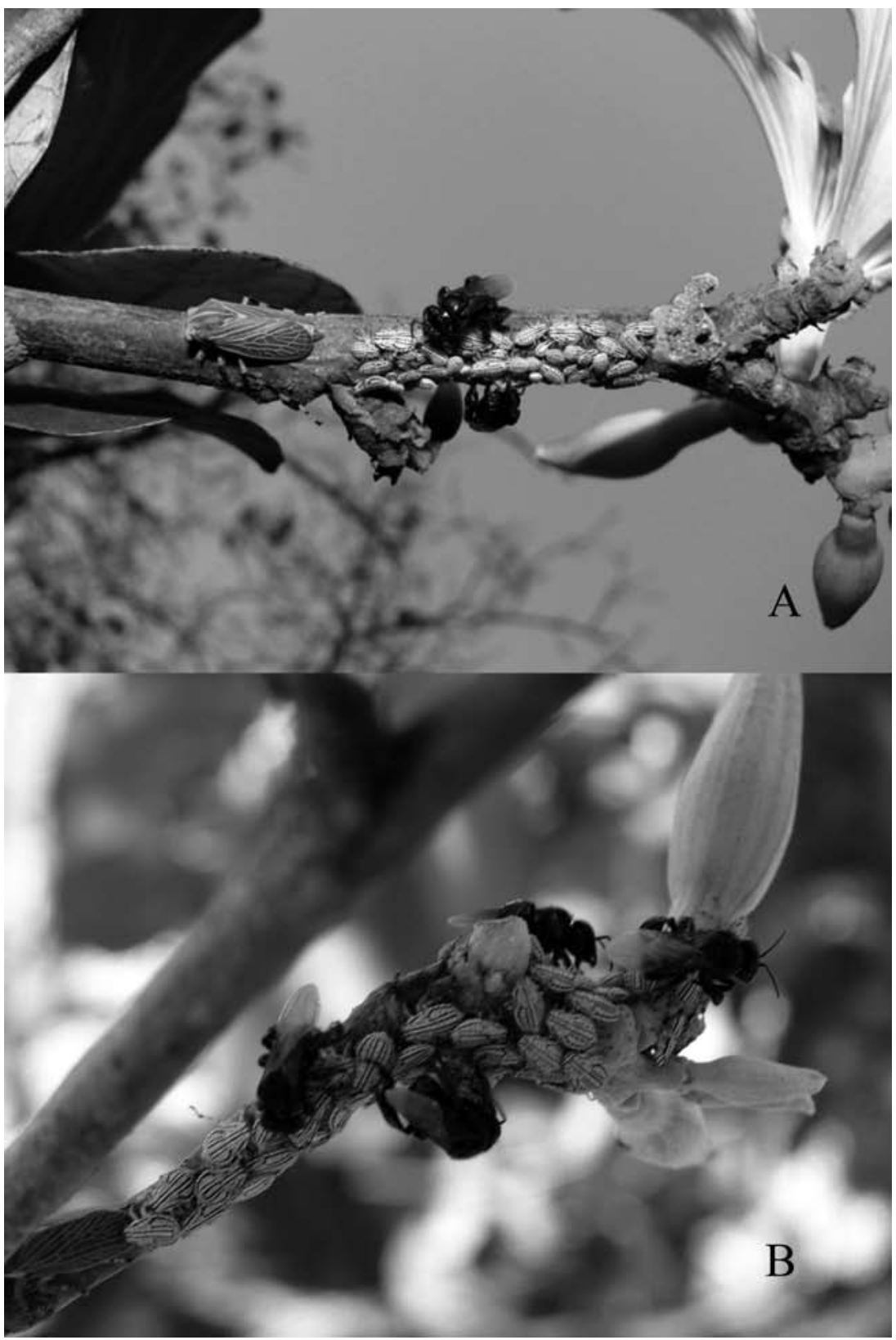

Fig. 1. Antennal stimulation by T. branneri on the distal part of $A$. reticulatum nymphs' abdomen, next to a flower of $B$. forficata in Parque Nacional das Emas, Goiás, Brazil (A). Note the number of Trigona bees on the colony of $A$. reticulatum (B). 


\section{DISCUSSION}

T. branneri has been registered eating and storing exudates of Terminalia argentea, and foraging in groups (Boff et al. 2008). However, Bittrich \& Amaral (1996) showed it as a nectar-thiefin Symphonia globulifera. Although the interaction between the stingless bee Trigona hyalinata Lepeletier, 1836 and Aethalion reticulatum and has already been observed (Oda et al. 2009), this paper is the first record of interaction between T. branneri and $A$. reticulatum.

In the interaction of $A$. reticulatum and T. spinipes on Mangifera indica, an exotic fruit species very common in Brazil, the Meliponines excite $A$. reticulatum individuals by walking over them. Initially the bees stay on treehoppers touching their antenna to the head of the insects and the first two pairs of legs on the back of the abdomen, after that beating the antennas on the distal part of the abdomen and quickly sucking the droplet released after stimulation (Vieira et al. 2007). In the same study the researchers also observed agonistic behavior in relation to other bees or ants of the Camponotus genus, although

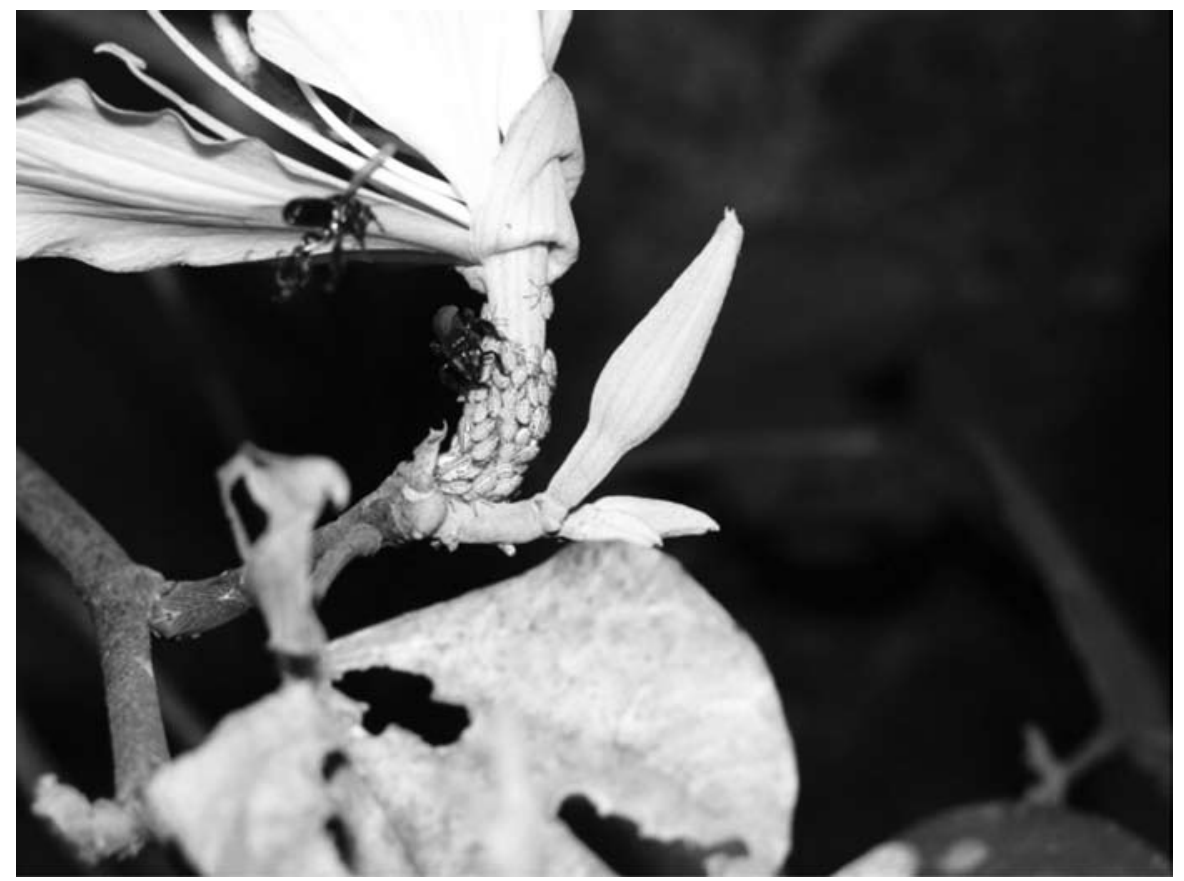

Fig. 2. T. branneri making a short flight over the A. reticulatum colony. 
the insects were less frequent in the period of greatest bee activity.

These interactions are determining factors for both species and community (Blüthgen et al. 2000; Wimp \& Whitham 2001; Styrsky \& Eubanks 2007). Wimp \& Whitham (2001) showed that aphids indirectly influence community structure by reducing the diversity of arthropods found in habitats where there is a mutualism with ants. In the same study, they experimentally showed that there is an effect of predators (top-down control) well as an effect of host plants (bottom-up) in aphid abundance. The association between aphids and ants is essential for survival in view of the negative top-down effects, and protection from predators the most important service provided by ants to the aphids (Wimp \& Whitham 2001). The authors also demonstrated that there is a dependence on ants for the establishment of aphids, as the number of aphids decreased as the distance from the nests of ants increased.

Although in our observations there is evidence that stingless bees could protect $A$. reticulatum we cannot say this with certainty, but in these kinds of interactions is common for the ants to protect the aphids in order to preserve the resource (honeydew) that is released by the aphids (Wimp \& Whitham 2001; Styrsky \& Eubanks 2007; Blüthgen \& Chung 2008).

We showed two interacting species possibly mutualistic, on $B$. forficata a host species commonly encountered in Brazilian regions. Thus, if T. branneri effectively provides protection for the aphids, this mutualism may be deserving of future studies to determine whether the bee-aphid interactions provide the same patterns or ecological functions as the ant-aphid interactions do (Styrsky \& Eubanks 2007).

\section{ACKNOWLEDGMENTS}

We thank Gabriel Melo and Helcio Gil Santana for their help in insect identification, the staff of Parque Nacional das Emas for logistical support and Estevão Alves da Silva for comments on the manuscript.

\section{REFERENCES}

Almeida, M.C. \& S. Laroca 1988. Trigona spinipes (Apidae, Meliponinae): Taxonomia, Bionomia e Relações Tróficas em Áreas Restritas. Acta Biologica Paranaense 17(14):67-108.

Bascompte, J. \& P. Jordano 2007. Plant-animal mutualistic networks: The architecture of biodiversity. Annual Review of Entomology 38(1):567-593. 
Boff, S., G. Graciolli, A.G. Boaretto \& M.R. Marques 2008. Insetos visitantes de gomas exsudadas por Terminalia argentea Mart \& Zucc (Combretaceae). Revista Brasileira de Entomologia 52(3):477-479.

Blüthgen, N., M. Verhaagh, W. Goitía, K. Jaffé, W. Morawetz \& W. Barthlott 2000. How plants shape the ant community in the Amazonian rainforest canopy: the key role of extrafloral nectaries and homopteran honeydew. Oecologia 125(1):229-240.

Blüthgen, N. \& A.Y.C. Chung2008. Ants in a Bornean rainforest: aggressive resource defence and a surprising case of tolerance. Antenna 32(1):38-47.

Brown, R.L. 1976. Behavioral observations on Aethalion reticulatum (Hemiptera, Aethalionidae) and associated ants. Insect Sociaux 23(1):99-108.

Castro, P.R.C. 1975. Mutualismo entre Trigona spinipes (Fabricius, 1793) e Aethalion reticulatum (L., 1767) em Cajanus indicus Spreng. na presença de Camponotus spp. Ciência e Cultura 27(1):537-539.

Del-Claro, K. 2004. Mulitrphic Relationships, Conditional Mutualisms, and the Study of Interaction Biodiversity in Tropical Savannas. Neotropical Entomology 33(6):665672

Fowler, H.G. 1992. Aethalionidae: functional equivalents of extrafloral nectaries in Baubinia (Caesalpinoideae). Anales de Biologia 18(1):155-159.

Gallo, D., O. Nakano, S. Silveira Neto, R.P.L Carvalho, G.C. Baptista, E. Berti Filho, J.R.P. Parra, R.A. Zucchi, S.B. Alves, J.D. Vendramim, L.C. Marchini, J.R.S. Lopes \& C. Omoto. 2002. Insetos úteis. In: Gallo, D. (ed.). Entomologia agrícola. $1^{\text {st }}$ ed. Livroceres, Piracicaba, Brasil: 219-242.

Letourneau, D.K. \& J.C. Choe 1987. Homopteran Attendance by waps and ants: The stochastic nature of interactions. Psysche 94(1):81-91.

Lorenzi, H. 2002. Árvores Brasileiras: Manual de Identificação e Cultivo de Plantas Arbóreas Nativas do Brasil. 4 ed. Instituto Plantarum.

Lorenzon, M.C.A., A.G. Rodrigues, \&J.R.G.C. Souza 1993. Comportamento polinizador de Trigona spinipes (Hymenoptera: Apidae) na florada da cebola (Allium cepa L.) híbrida. Pesquisa Agropecuária Brasileira 28(1):217-221.

Maués, M.M. \& G. Couturier 2002. Biologia floral e fenologia reprodutiva do camu-camu (Myrciaria dúbia (H.B.K.) Mc Vaugh, Myrtaceae) no Estado do Pará, Brasil. Revista Brasileira de Botânica 25(1):441-448.

MacCarroll, M.A. \& Reeves, W.K. 2004. Attendance of Aethalion reticulatum (Hemiptera: Aetalionidae) by Polisteserythrocephalus (Hymenoptera:Vespidae)in Peru. Entomological News 115(1):52-53.

Michener, C.D. 2000. The Bees of the World. In: Michener, C.D. (ed.). Tribo meliponini. $2^{a}$ ed. The Johns Hopkins University Press. Baltimore, EUA: 803-829.

Murphy, C.M. \& Breed, M.D. 2008. Nectar and resin robbing in stingless bees. American Entomologist 54(1):36-44.

Nogueira-Neto, P. 1997. Vida e Criação de Abelhas Indígenas sem Ferrão. In: NogueiraNeto, P. (ed.). Características diversas, distribuição geográfica e aclimatação. Editora Nogueirapis, São Paulo, Brasil: 33-38. 
Oda, F.H., C. Aoki, T.M. Oda, R.A. Silva \& M.F. Felismino 2009. Interação entre abelha Trigona hyalinata (Lepeletier, 1836) (Hymenoptera: Apidae) e Aethalion reticulatum Linnaeus 1767 (Hemiptera: Aethalionidae) em Clitoria fairchildiana Howard (Papolionoideae). Entomobrasilis 2(2):58-60.

Ramoni-Perazzi, P., G. Bianchi-Perez \& G. Biachi-Ballesteros 2006. Primer registro de asociación entre Aethalion reticulatum (Linné) (Hemiptera: Aethalionidae) e Synoeca septentrionalis Richards (Hymenoptera: Vespidae). Entomotropica 21(2):129-132.

Santana, D.L.Q., C.A. Ferreira, E.G. Martins \& H.D. Silva. 2005. Ocorrência de Aethalion reticulatum (Linnaeus, 1767) (Hemiptera: Aethalionidae) em Grevillea robusta. Boletim de Pesquisa Florestal 50(1):109-115.

Santos, C.F. \& M.L. Absy 2010. Polinizadores de Bertholletia excelsa (Lecythidales: Lecythidaceae): interações com abelhas sem ferrão (Apidae: Meliponini) e nicho trófico. Neotropical Entomology 39(6):854-861.

Silva, C.I., S.C. Augusto, S.H. Sofia \& I.S. Moscheta. 2007. Bee diversity in Tecoma stans (L.) Kunth (Bignoniaceae): Importance for pollination and fruit production. Neotropical Entomology 36(3):331-341.

Silva, M.M., C.H. Buckner, M. Picanço, \& C.D. Cruz 1997. Influência de Trigona spinipes Fabr. (Hymenoptera: Apidae) na polinização do Maracujazeiro Amarelo. Anais da Sociedade Entomológica do Brasil 26(2):217-221.

Stadler, B., \& A.F.G. Dixon 2005. Ecology and evolution of aphid-ant interactions. Annual Review of Entomology 36(1):345-372.

Styrsky,J.D. \& M.D. Eubanks 2007. Ecological consequences of interactions between ants and honeydew-producing insects. Procedings of Royal Society B, 274(1607):151-164.

Vaz, A.M.S.F. 2010. Bauhinia: Lista de Espécies da Flora do Brasil. Jardim Botânico do Rio de Janeiro. Avaliable from http://floradobrasil.jbrj.gov.br/2010/FB082666 (accessed 19 September 2011).

Vieira, C.U., C.M. Rodovalho,L.O.Almeida, A.C.S.Siqueroli \& A.M.Bonetti2007.Interação entre Trigona spinipes Fabricius 1793 (Hymenoptera: Apidae) e Aethalion reticulatum Linnaeus 1767 (Hemiptera: Aethalionidae) em Mangifera indica (Anacardiaceae). Bioscience Journal 23(1):10-13.

Way, M.J. 1963. Mutualism between ants and honeydew-producing homóptera. Annual Review Entomological 8(1):307-344.

Wimp, G. M. \& T.G. Whitham 2001. Biodiversity consequences of predation and host plant hybridization on an aphid-ant mutualism. Ecology 82(2):440-452.

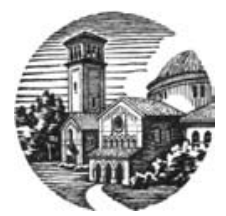

